\title{
Patent Analysis for Pyroprocessing of Spent Nuclear Fuels
}

\section{사용후핵연료 파이로처리기술의 특허 동향 분석}

Jae-Hyung Yoo'), Jung-Kuk Kim, Han-Soo Lee, In-Seok Seo* and Eun-ka Kim*

Korea Atomic Energy Research Institute, 1045 Daedeok-daero, Yuseong-gu, Daejeon, Korea

유재형1), 김정국, 이한수, 서인석*, 김은가*

한국원자력연구원, 대전광역시 유성구 대덕대로 1045

*대덕원자력포럼, 대전광역시 유성구 대덕대로 1045

(Received October 25, 2011 / Revised November 14, 2011 / Approved November 15, 2011)

\begin{abstract}
Analysis of foreign and domestic patents for pyroprocessing technology of spent nuclear fuels was carried out in this study. The current status of pyroprocessing technology development in such countries as Korea, USA, Japan and EU was analyzed by classifying the patents for 1975 through 2009 according to registration country, assignee, calendar year and technology area. The major assignees' activity indices were compared in order to find out whether there is any concentrated area of technical details. Technology competitiveness of the countries was also investigated from the information of patent citation number and family size. Furthermore, some essential unit technologies required for the commercialization of pyroprocessing were derived and examined in the aspect of the state of art as well as the trend of technology development.
\end{abstract}

Key words : Patent analysis, Pyroprocessing, Electrochemical reduction, Electrorefining, Electrowinning, Molten salt waste

\section{요 약}

사용후핵연료의 파이로처리기술에 대한 국내외 특허동향을 분석하였다. 1975-2009년에 걸쳐 한국, 미국, 일 본 및 유럽연합에서 출원된 특허에 대하여 출원국별, 출원인별, 연도별 및 세부기술분야별로 구분하여 그 내 용을 비교함으로써 파이로처리기술 개발 현황을 분석하였다. 그리고 주요 출원인의 세부기술별 특허활동지수 로부터 특정분야의 기술개발 편중도, 분석대상 특허의 피인용횟수와 패밀리수로부터 각국의 기술 경쟁력을 조사하였다. 또 장차 파이로처리기술의 실용화에 대비하여 필수 요소기술들을 도출하고 그에 대한 현기술 수 준과 기술개발동향 등을 파악하였다.

중심단어 : 특허동향분석, 파이로처리기술, 전해환원, 전해정련, 전해제련, 용융염 폐기물

\section{I. 서 론}

1) Corresponding Author. E-mail : njhyou@kaeri.re.kr 
상용 원자로에서 배출되는 사용후핵연료는 고방사능과 고 발열량을 띠고 있는 위험 물질이다. 따라서 상용 원자력발전 을 실시하는 나라에서는 사용후핵연료의 궁극적인 관리 방법 으로 현재 두 가지를 고려하고 있다. 먼저 순환핵연료주기를 채택하는 나라에서는 사용후핵연료 재처리를 통하여 다시 핵 연료로 쓸 수 있는 우라늄과 플루토늄을 회수해낸 후 나머지 폐기물 즉, 고준위 방사성폐기물을 유리 형태의 고화체로 만 든 후 장차 심지층의 암반 중에 영구처분하는 방법을 계획하 고 있다. 한편, 비순환 핵연료주기를 채택하는 나라에서는 사 용후핵연료를 재처리하지 않고 사용후핵연료 그 자체를 고준 위 방사성폐기물로 간주하여 처분용기인 캐니스터에 넣고 밀 봉한 후 심지층에 영구처분하는 방법을 계획하고 있다. 이 두 가지 방법에서 고준위폐기물이나 사용후핵연료는 모두 고방 사능과 고발열량을 띠고 있기 때문에 인간의 생활환경으로부 터 완전히 격리시킬 수 있도록 안전하게 영구처분하는 기술 이 필요하며, 이를 달성하기 위하여 우리나라를 비롯한 세계 여러 나라에서 활발한 연구개발이 수행되고 있다.

사용후핵연료를 재처리하기 위하여 지금까지는 PUREX (Plutonium and Uranium Extraction) 라고 하는 습식 재처리 기술에 의존해 왔으나 이 공정에서는 순수한 플루토늄이 최 종제품의 하나로 생산되기 때문에 이는 항상 핵확산 위험성 을 내포하고 있다. 따라서 최근에는 핵확산을 방지할 수 있는 핵연료주기기술의 개발이 국제사회로부터 강력히 요구되고 있으며 그 일환으로 연구개발되고 있는 것이 바로 파이로처 리기술이다. 사용후핵연료 파이로처리 과정에서 얻어지는 최 종제품은 두 가지가 있는데 그중 하나는 순수한 우라늄이고 또 다른 하나는 우라늄과 초우라늄원소들(우라늄보다 원자번 호가 큰 원소 즉, 넵투늄, 플루토늄, 아메리슘, 퀴륨 등)이 혼 합된 악티늄족 혼합물이다.

이 초우라늄원소들은 천연에는 존재하지 않고 모두 인위적 으로 만들어지는 인공원소들이며 대부분 장반감기 핵종으로 구성되어 있다. 따라서 이들이 영구처분되는 방사성폐기물에 함유되어 있을 경우 그 영구처분 조건은 대단히 엄격하다. 한 가지 예로 그것들을 생활환경으로부터 완전히 격리시키기 위 해서는 반드시 심지층의 암반 중에 처분하여야만 한다. 그리 고 처분 후 처분용기 주변의 빈 공간을 점토와 같이 흡착성이 강한 충진재로 완전히 밀봉하여 설사 지하수가 그곳까지 침 투해 들어가더라도 지하수 흐름을 따라 핵종이동이 일어나지 않도록 해야 한다는 것이다. 만약 영구처분되는 방사성폐기 물로부터 장반감기 핵종들을 완전히 제거할 수 있다면 나머 지 폐기물은 그 처분조건이 크게 완화되어 처분비용 또한 대
폭 줄어들 것이다. 또 한 가지 이점은 초우라늄원소 혼합물 제 품이 상당량의 불순물 즉, 핵분열 생성물을 포함하고 있어 이 들이 $\gamma$-방사선을 방출하고 있기 때문에 핵확산 우려에 대한 자체방어력을 보유하고 있다는 것이다. 그러므로 설령 불순 분자들이 무단으로 침입하여 그 제품을 훔쳐가서 악용한다 하더라도 그 취급이 용이하지 않기 때문에 이는 핵물질의 안 전관리 측면에서 오히려 유리하게 작용할 수 있다는 것이다. 그 밖에 또 한 가지의 분명한 이점은 그 악티늄족 혼합물을 장 차 에너지원으로 재활용할 수 있다는 것이다. 가까운 미래에 실용화될 것으로 기대되는 차세대 고속원자로의 연료로 사용 될 수 있을 것이라는 전망 때문이다. 고속중성자 스펙트럼을 갖는 원자로〔1]에서는 초우라늄원소들도 핵분열을 일으킬 수 있도록 고안되고 있으므로 연료 속에 함유된 장수명 핵종들 이 핵분열에 의하여 단수명 핵종으로 변환되며, 그 결과 최종 폐기물이 단수명 핵종으로만 남아 있게 되므로 이는 장차 고 준위폐기물의 관리에 상당한 이점을 가져올 수 있을 것으로 예상되기 때문이다. 즉, 처분 폐기물에 함유된 방사성 핵종의 반감기가 짧으면 방사선 붕괴가 더 급속하게 진행되므로 이 는 처분장 폐쇄 후의 관리기간을 대폭 줄일 수 있고 또 폐기물 의 처분 조건을 완화시킬 수 있으므로 그에 따른 처분 비용의 절감이 예상되기 때문이다.

이러한 맥락에서 우리나라를 비롯한 미국, 일본, 러시아, 유럽연합 등 여러 나라에서 파이로 처리 기술을 연구개발하 고 있으며 새로운 결과들이 속속 특허로 출원되고 있다. 이에 따라 한국원자력연구원에서는 사용후핵연료 파이로처리기술 분야의 기술개발 동향 및 추이를 파악하기 위하여 특허법인 체인 화우사와 함께 특허동향 조사〔2〕를 수행하였으며 또, 우 리나라 원자력환경에 적합한 고준위폐기물 관리기술 선행 조 사 · 분석 연구〔3〕를 대덕원자력포럼에 의뢰하여 수행한 바 있다. 따라서 본 연구에서는 그들의 연구내용과 특허동향 조 사 - 분석 결과를 바탕으로 파이로처리기술 개발 현황과 전망 그리고 파이로처리기술 실용화에 대비한 필수 요소기술의 내 용을 파악하고자 하였다.

\section{II. 특허출원 동향 분석}

\section{가. 국가별 및 연도별 출원 동향}

사용후핵연료 파이로처리기술 분야의 특허 출원은 1975년 이래 꾸준히 증가하는 경향을 보여 왔다(Fig.1 참조). 1975 2009년 동안 각국에 출원된 누적건수는 일본이 160 건 (52.5\%)으로 가장 많고 그 뒤를 이어 미국이 83건 (27.2\%), 한 국이 43건 (14.1\%), 그리고 유럽연합이 19건 (6.2\%)을 차지하 
였다. 한편, 이를 연도별로 도시해보면 Fig. 2에 보는 바와 같 다. 이 그림에서 보듯이 일본에 출원된 특허건수는 '80년대 후반부터' 90년대 중반에 걸쳐 큰 폭으로 증가하였으나 2000 년대 이후에는 다소 감소하는 경향을 나타내었다. 미국의 경 우도 '80년대와' 90년대에는 꾸준히 증가하였으나 2000년대 이후에는 다소 감소하는 경향을 보이고 있다. 한편, 우리나라 의 경우 '80년대에는 특허 출원이 거의 없었으나 (사실상 이 시기에는 연구개발 활동이 미미하였던 것이 그 원인임)' 90 년 대 후반부터 점점 증가하는 경향을 띠고 있다.

\section{나. 국가별 및 출원인 국적별 세부기술 분야의 분포}

우리 나라에서 현재 운용되고 있는 상용 경수로의 이산화 우라늄 연료를 파이로처리의 대상으로 삼을 경우 사용후핵 연료 파이로처리기술은 다음과 같이 크게 4 분야로 나눌 수 있다. 즉, 전해환원, 전해정련, 전해제련 및 염폐기물 재생/ 고화 분야가 그것이다. 이를 국가별로 출원인의 국적 분포 및 세부기술 분야의 분포를 표시하면 Table1에 보는 바와 같 다. 이 표에서 보듯이 한국과 일본에서는 자국인의 출원율이 외국인 출원율에 비하여 훨씬 더 크다는 것을 알 수 있다. 그 리고 미국은 자국인과 외국인의 출원율이 거의 유사하며, 유 럽연합은 비유럽인의 출원율이 오히려 더 큰 결과를 보여주 고 있다. 한편, 세부기술 분야의 분포에 있어서는 어느 나라 나 한 특정분야에만 치우치지 않고 상기 4분야에 있어 비교

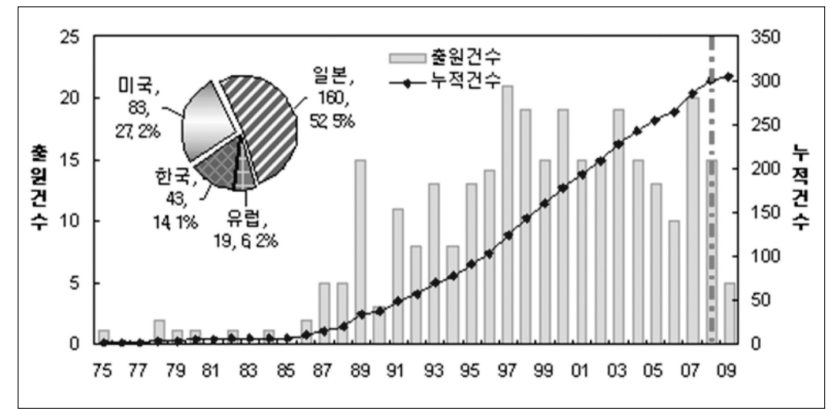

Fig. 1. Number of patents issued by year and that accumulated during $1975 \sim 2009$ in the area of pyroprocessing in the countries of Korea, USA, EU and Japan.

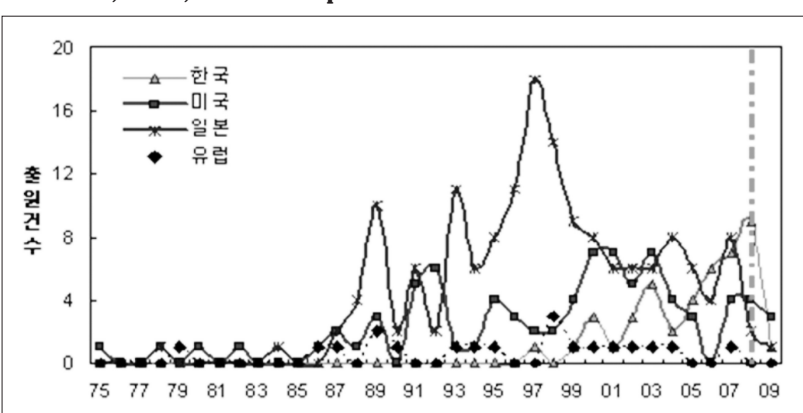

Fig. 2. Number of patents by year in each country.
적 고른 분포를 나타내고 있음을 알 수 있다.

\section{다. 세부기술 분야별 및 출원인별 출원 동향}

앞에서 언급한 조사 - 분석 대상 특허를 세부기술 분야별, 그리고 출원인별 분포를 살펴보면 Table 2 와 같다. 이 표에 서 보는 바와 같이 출원건수가 가장 많은 출원인은 한국원자 력연구원 (72건)이며 그 뒤를 이어 일본의 도시바사 (70건), 미국 에너지성 (55건), 일본 원자력위원회 (40건)의 순서를 보이고 있다. 또 세부기술 분야별로 살펴보면 4 개 분야에 비 교적 고른 분포를 보이고 있으나 그 중에서도 전해정련 분야 의 특허가 가장 많이 출원되었다.

이를 특허활동지수 (Activity Index; A.I.)로 나타내면 Table 3에 보는 바와 같다. 특허활동지수는 다음과 같은 공 식에 의하여 산출되며,

$$
\text { A.I. }=\frac{\frac{\text { 특정기술 분야의 특정출원인 건수 }}{\text { 특정기술분야 전체건수 }}}{\frac{\text { 특정 출원인 총건수 }}{\text { 전체 총건수 }}}
$$

이는 해당 출원인의 특정 기술 분야에 대한 상대적 편중도 를 파악할 수 있는 지표가 된다. 즉, 그 값이 "1"인 경우를

Table 1. Number of patents, assignee's nationality and technology area for the patents issued during $1975 \sim 2009$ in each country.

\begin{tabular}{|c|c|c|c|c|c|c|c|c|}
\hline \multirow{2}{*}{ 국가 } & \multirow{2}{*}{ 출원건수 } & \multicolumn{2}{|c|}{ 출원인 국적 (\%) } & \multicolumn{5}{|c|}{ 세부기술 분야 (\%) } \\
\cline { 3 - 9 } & & 자국인 & 외국인 & 전해환원 & 전해정련 & 전해제련 & 염폐기물 & 기타 \\
\hline 한국 & 43 & 77 & 23 & 30 & 24 & 12 & 26 & 8 \\
\hline 일본 & 160 & 83 & 17 & 19 & 34 & 20 & 11 & 16 \\
\hline 미국 & 83 & 51 & 49 & 22 & 26 & 28 & 16 & 8 \\
\hline 유럽연합 & 19 & 37 & 63 & 30 & 22 & 13 & 13 & 22 \\
\hline
\end{tabular}

Table 2. Number of patents of the major assignees in each techology area.

\begin{tabular}{|c|c|c|c|c|c|}
\hline \multirow{2}{*}{ 세부기술 분야 } & \multicolumn{5}{|c|}{ 출원건수 } \\
\cline { 2 - 6 } & $\begin{array}{c}\text { 한국원자력 } \\
\text { 연구원 }\end{array}$ & 도시바사 & 미국에너지성 & $\begin{array}{c}\text { 일본원자력 } \\
\text { 위원회 }\end{array}$ & 계 \\
\hline 전해환원 & 26 & 9 & 6 & 7 & 48 \\
\hline 전해정련 & 16 & 28 & 17 & 9 & 70 \\
\hline 전해제련 & 7 & 21 & 22 & 7 & 57 \\
\hline 염폐기물재생 ·고화 & 17 & 8 & 7 & 7 & 39 \\
\hline 기타 & 6 & 4 & 3 & 10 & 23 \\
\hline & 72 & 70 & 55 & 40 & 237 \\
\hline
\end{tabular}

Table 3. Activity indices of the major assignees.

\begin{tabular}{|c|c|c|c|c|}
\hline \multirow{2}{*}{ 세부기술 분야 } & \multicolumn{4}{|c|}{ 특허활동지수 } \\
\cline { 2 - 5 } & $\begin{array}{c}\text { 한국원자력 } \\
\text { 연구원 }\end{array}$ & 도시바사 & 미국에너지성 & $\begin{array}{c}\text { 일본원자력 } \\
\text { 위원회 }\end{array}$ \\
\hline 전해환원 & 1.78 & 0.63 & 0.54 & 0.86 \\
\hline 전해정련 & 0.75 & 1.35 & 1.05 & 0.76 \\
\hline 전해제련 & 0.40 & 1.25 & 1.66 & 0.73 \\
\hline 염폐기물 & 1.43 & 0.69 & 0.77 & 1.06 \\
\hline 기타 & 0.86 & 0.59 & 0.56 & 2.58 \\
\hline
\end{tabular}


기준으로 1 보다 더 크면 편중도가 강하고 1 보다 더 작으면 편중도가 약함을 의미한다. Table2에 보는 바와 같이 어느 출원인이나 분야별 편중도가 거의 없이 비교적 고른 분포를 나타내고 있으며 이는 파이로처리기술 개발이 어느 특정 분 야에만 국한되지 않았음을 말해 준다.

\section{라. 국가별 주요 출원인}

사용후핵연료 부피감용기술 분야에 있어 각국의 다수 특 허 출원인을 살펴보면 다음과 같다. 즉, 한국원자력연구원이 56 건을 출원하여 다수 출원인 1 위의 자리를 차지하였으며 그 뒤를 일본의 도시바사 (49건), 미국의 에너지성 (31건), 일본 원자력위원회 (31건), 영국 핵연료공사 (17건)의 순으 로 이어지고 있다. Table 4 에 보는 것은 한국, 미국, 일본 및 유럽연합 특허의 주요 출원인을 표시한 것이다. 이들 특허에 서 연도구간별 기술 선도기관을 조사해보면 2000년을 기준 으로 하여 그 이전에는 일본의 도시바사와 원자력위원회 그 리고 미국의 에너지성 등이 차지하였으나 그 이후에는 한국 원자력연구원이 새로운 선도기관으로 등장하여 외국의 선도 기관들에 뒤지지 않는 다수의 기술개발 실적을 쌓아나가고 있다.

\section{마. 주요 국가의 기술 경쟁력 비교 분석〔2〕}

어떤 특허의 피인용빈도수는 일반적으로 그 특허의 기술 적 수준을 나타내는 척도로 사용된다. 이를 통상 인용도지수 (CPP: Citation Per Patent)라고 부르며 다음과 같이 정의된 다.

Table 4. Top 10 assignees in each country.

\begin{tabular}{|c|c|c|c|c|c|c|c|c|}
\hline \multirow{2}{*}{ 순위 } & \multicolumn{2}{|l|}{ 한 국 } & \multicolumn{2}{|l|}{ 미 국 } & \multicolumn{2}{|l|}{ 일 본 } & \multicolumn{2}{|l|}{ 유럽연합 } \\
\hline & 특허권자 & 건수 & 특허권자 & 건수 & 특허권자 & 건수 & 특허권자 & 건수 \\
\hline 1 & $\begin{array}{c}\text { 한국원자력 } \\
\text { 연구원 }\end{array}$ & 33 & 미국에너지성 & 27 & 일본 도시바 & 46 & $\begin{array}{c}\text { 영국 British } \\
\text { Nuclear Fuels }\end{array}$ & 4 \\
\hline 2 & $\begin{array}{l}\text { 영국 British } \\
\text { Nuclear Fuels }\end{array}$ & 4 & $\begin{array}{c}\text { 한국원자력 } \\
\text { 연구원 }\end{array}$ & 13 & $\begin{array}{l}\text { 일본원자력 } \\
\text { 위원회 }\end{array}$ & 20 & $\begin{array}{c}\text { 일본원자력 } \\
\text { 위원회 }\end{array}$ & 3 \\
\hline 3 & $\begin{array}{c}\text { 핀란드 } \\
\text { Outokumpu } \\
\text { Oyj }\end{array}$ & 2 & $\begin{array}{c}\text { 일본원자력 } \\
\text { 위원회 }\end{array}$ & 8 & 일본 하타치 & 14 & $\begin{array}{c}\text { 핀란드 } \\
\text { Outokumpu } \\
\text { Oyj }\end{array}$ & 2 \\
\hline 4 & $\begin{array}{c}\text { 카나다 } \\
\text { Atomic Energy }\end{array}$ & 1 & \begin{tabular}{c|} 
영국 British \\
Nuclear Fuels
\end{tabular} & 4 & 일본 CRIEPI & 12 & 미국에너지성 & 1 \\
\hline 5 & $\begin{array}{c}\text { 프랑스 } \\
\text { COGEMA }\end{array}$ & 1 & 일본 도시바 & 3 & $\begin{array}{c}\text { 한국원자력 } \\
\text { 연구원 }\end{array}$ & 10 & 프랑스 CEA & 1 \\
\hline 6 & $\begin{array}{c}\text { 일본 NIKKO } \\
\text { Materials }\end{array}$ & 1 & \begin{tabular}{c|} 
핀란드 \\
Outokumpu \\
Oyj
\end{tabular} & 2 & $\begin{array}{c}\text { 일본 } \\
\text { MITSUBISHI } \\
\text { Materials }\end{array}$ & 7 & $\begin{array}{c}\text { 프랑스 } \\
\text { COGEMA }\end{array}$ & 1 \\
\hline 7 & $\begin{array}{l}\text { 일본 Seimi } \\
\text { Chemical }\end{array}$ & 1 & $\begin{array}{l}\text { 미국 Rockwell } \\
\text { International }\end{array}$ & 2 & \begin{tabular}{|c|} 
영국 British \\
Nuclear Fuels \\
\end{tabular} & 5 & $\begin{array}{c}\text { 이탈리아 } \\
\text { Electtrochimica }\end{array}$ & 1 \\
\hline 8 & & & \begin{tabular}{c|} 
독일 \\
Studiengesel \\
lschaft Kohle
\end{tabular} & 2 & 미국에너지성 & 3 & $\begin{array}{c}\text { 일본 Japan } \\
\text { Nuclear Fuel }\end{array}$ & 1 \\
\hline 9 & & & 미국시카고대 & 2 & $\begin{array}{c}\text { 일본 NIKKO } \\
\text { Materials }\end{array}$ & 3 & \begin{tabular}{|c|} 
독일 \\
Kernforschu \\
ngszentrum, \\
Karlsruhe
\end{tabular} & 1 \\
\hline 10 & & & $\begin{array}{c}\text { 카나다 } \\
\text { Atomic Energy }\end{array}$ & 1 & $\begin{array}{c}\text { 일본 Nippon } \\
\text { Nuclear fuel } \\
\text { Dev. }\end{array}$ & 3 & $\begin{array}{c}\text { 일본 NIKKO } \\
\text { Materials }\end{array}$ & 1 \\
\hline
\end{tabular}

$$
C P P=\frac{\text { 피인용회수 }}{\text { 특허건수 }}
$$

그리고 또 다른 지수 PFS(Patent Family Size)는 시장 확보 력을 나타내는 지수로 사용되며 그 정의는 다음과 같다.

$$
P F S=\frac{\text { 특허패밀리수 }}{\text { 특허건수 }}
$$

그러므로 이 두 가지 지수가 높을수록 해당 특허의 기술 경쟁력이 큰 것으로 분석된다. 앞서 언급한 분석 대상 특허 에 대하여 이 지수들의 평균치는 $\mathrm{CPP}$ 가 4.0, PFS가 4.6으로 계산되었으며, 이들을 기준으로 각국의 기술 경쟁력을 도시 해보면 Fig.3과 같다. $\mathrm{CPP}$ 의 평균치를 상회하는 국가는 미 국, 프랑스, 독일 등이며 PFS의 평균치 4.6 을 상회하는 국가 는 영국, 일본, 프랑스, 독일로 판명되었다. 그러나 우리나라 는 아직 $\mathrm{CPP}$ 나 PFS에 있어 세계 평균치를 밑도는 것으로 나 타났다.

\section{바. 기술개발 매트릭스의 구성 및 분석}

본 절에서는 각 세부기술 분야에 있어서 분석 대상 특허의 기술개발 목적과 그 목적달성수단을 조사하여 목적-목적달 성수단 사이의 기술개발 매트릭스를 구성하였다. 이 기술개 발 매트릭스를 3차원 그림으로 도시해보면 각 세부기술 분 야에 있어서 기술개발 활동이 어떤 방향으로 전개되고 있는 지 그 추이를 쉽게 파악할 수 있기 때문이다. 본 연구에서는 각 세부기술 분야의 공통적인 기술개발 목적으로 회수율 증 대, 생산성 증대, 공정의 안전성 향상, 폐기물 발생량의 저감 등을 선택하였으며 또 목적달성수단으로는 반응조 개량, 전 극체 개량, 조업조건 개선, 반응매질 개량, 증류/주조장치 개 량, 기타 장치 개량 등의 항목을 선택하였다. 각 세부기술 분 야에 대한 기술개발 매트릭스를 3차원으로 도시하여 Fig. 4 와

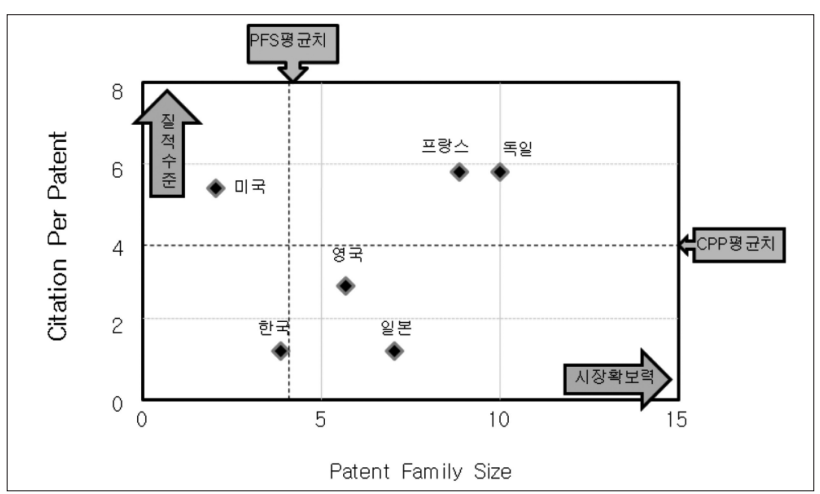

Fig. 3. Technology competitiveness of the major countries in the area of volume reduction of spent nuclear fuels. 
같은 결과를 얻었다.

이 결과로부터 전해환원, 전해정련 및 전해제련 과정에 있 어서는 대부분의 특허가 장치 개량에 초점을 두고 있음을 알 수 있다. 그리고 그 목적은 악티늄족 원소의 회수율 증대, 공 정의 생산성과 안전성 증대에 치중되어 있음을 알 수 있다. 한편, 염폐기물 재생/고화처리 분야에 있어서는 용융염 재생 율 증대와 폐기물 발생량 저감을 지향하는 것이 기술 개발의 가장 큰 목적임을 알 수 있다.

\section{III. 파이로처리공정 실용화를 위한 신기술 개발 동향}

사용후핵연료의 파이로처리기술은 현재 우리나라를 비롯한 몇몇 나라(미국, 일본, 유럽연합, 러시아 등)에서 연구개발을 수 행하고 있지만 아직 어느 나라도 상용화 수준까지는 이르지 못 하고 있다. 장차 이 기술을 실용화하기 위해서는 아직도 해결해 야 할 기술적 문제들이 많이 남아 있기 때문이다. 따라서 세계 여러 나라에서 파이로처리 분야의 연구개발이 꽤 활발하게 수 행되고 있으며, 그 결과 기존의 기술보다 더 향상되고 개선된 신기술이 지속적으로 개발되고 있다. 그리고 그 결과들이 속속 특허출원으로 이어지고 있어 이 분야의 특허 기술들을 조사 . 분석해봄으로써 기술 개발의 추이, 기술 수준, 파이로처리 과정 에 있어서의 적용 가능성 등을 쉽게 파악할 수 있을 것이다. 따 라서 이러한 맥락에서 본 연구에서는 파이로처리기술 분야에 있어서 지금까지 출원된 여러 나라 특허의 기술적 내용을 살펴
보고자 하였다. 사용후핵연료 파이로처리 과정에 있어 세부기 술 분야는 우라늄산화물의 환원, 용융염 전해정련, 용융염 전해 제련, 용융염 폐기물의 처리 등이다. 그 외에도 파이로처리 공 정을 대형화/상용화하기 위해서는 다음과 같은 필수 요소기술 이 먼저 확보되어야 할 것이다. 즉, 산화물 연료의 화학적 환원, 연속식 전해정련, 고온 액상 용융염의 취급, 용융염 재생, 전해 제련에 의한 초우라늄원소 회수 그리고 폐용융염 고화처리 등 이다. 이러한 기술이 확보되어 파이로처리기술을 바탕으로 한 새로운 핵연료주기가 확립된다면 이는 핵확산 방지, 초우라늄 원소들의 에너지 자원화, 장반감기 핵종 소멸 등의 장점을 보유 한 획기적인 핵연료주기가 될 것이다. 이러한 배경 하에 본 연 구에서 추진하고자 하는 것은 지금까지 출원된 파이로처리 분 야의 국내 · 외 특허 가운데 실용성이 크다고 판단되는 필수 요 소기술들을 발췌하여 그 기술현황 및 기술개발동향을 파악, 분 석해보고자 하였으며 앞으로 이 분야의 공정 및 기기장치 실용 화에 대비하여 중요한 참고자료가 될 수 있을 것이다.

\section{가. 산화물 연료의 환원}

금속산화물 형태의 사용후핵연료를 건식 전해정련 및 전 해제련법으로 처리하기 위해서는 먼저 금속산화물을 금속 형태로 환원시킬 필요가 있다. 여기에는 크게 두 가지 방법 이 있는데 그 중 하나는 화학적인 방법이고 다른 하나는 전 기화학적인 방법이다. 화학적 환원과정에서는 금속환원제인 리튬, 칼슘 등이 주로 사용되고 있으며 전기화학적인 환원과

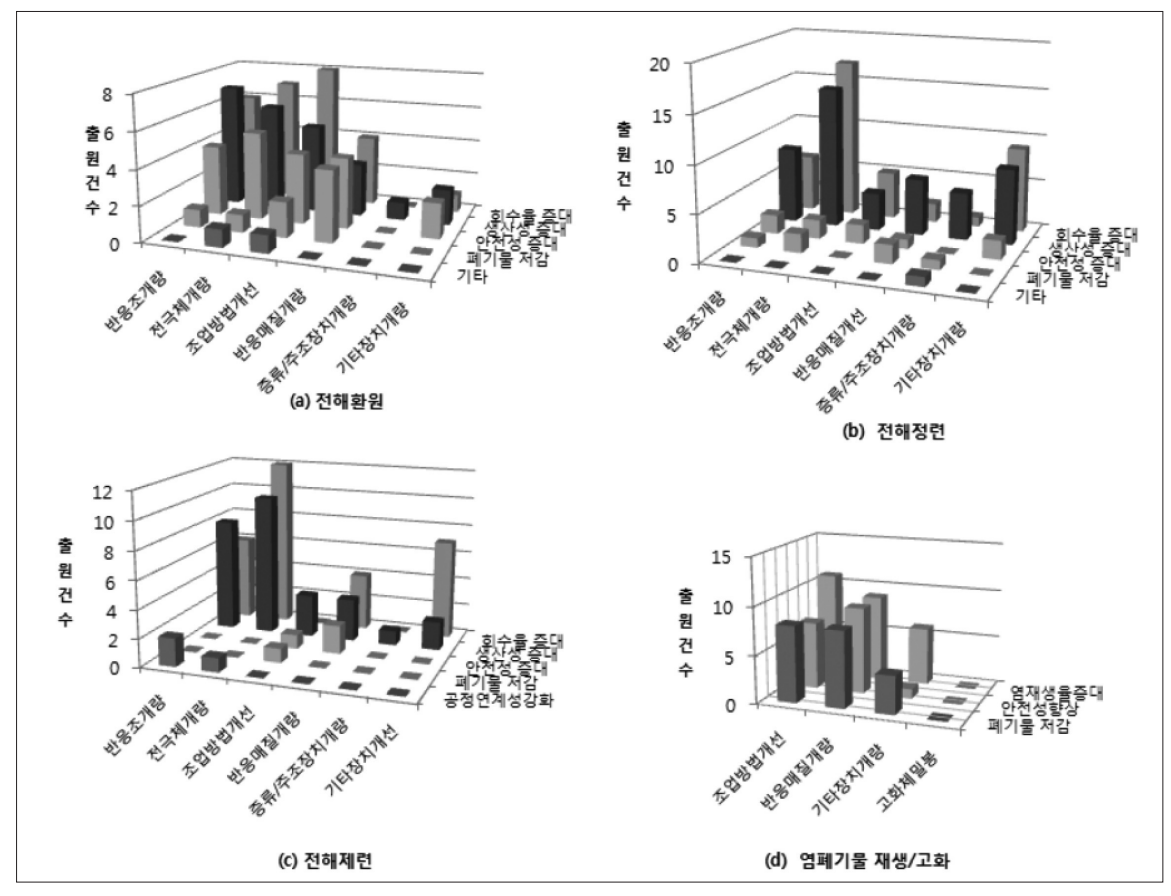

Fig. 4. The matrix between technical issues and technical approaches for each technology area. 
정에서는 본 항목의 중간 부분에 기술한 바와 같이 2 단계의 반응과정을 거쳐서 금속으로 전환된다.

당초 미국의 아이다호 국립연구소에서 파이로처리기술 개 발을 시도할 때는 대상 핵연료로 EBR-II (Experimental Breeder Reactor-II)에서 배출되는 금속 핵연료를 사용하였 기 때문에, 금속산화물의 환원과정이 필요치 않아 이 분야의 특허가 많지 않았으며, 이는 지금까지도 그렇다. 그러나 전 세계 상용 원자로에 사용되는 핵연료는 대부분 금속산화물 이며 이를 처리 대상물로 삼기 위해서는 산화물 환원기술이 절대적으로 필요한 요소기술이다. 최근 미국에서 출원, 등록 된 한 특허 [4]의 내용을 살펴보면 다음과 같은 전해환원기 술의 장점이 제시되고 있다. 즉, 전해환원법은 화학적 환원 법에 비하여 여러 가지의 장점을 가지고 있는데 그것은 단일 용기 내에서 단일 처리과정으로 운전할 수 있기 때문에 공정 이 간단하며, 과잉량의 환원제가 필요치 않고, 반응도 제어 용이, 반연속식 운전 가능, 부산물이 산소 뿐이므로 환경친 화적, 고순도 제품 획득, 차폐공간(핫셀) 소요가 적으므로 처 리비용 절감 등의 이점을 실현시킬 수 있다는 것이다. 또한 이 특허에서 제시한 주요 기술적 사항을 살펴보면 다음과 같 다. 환원 대상물인 각종 금속산화물에 대하여 적절한 전해질 의 선택, 환원제용 산화물 $\left(\mathrm{LiCl}\right.$ 전해질의 경우 $\left.\mathrm{Li}_{2} \mathrm{O}\right)$ 의 제한 농도(예: $\mathrm{LiCl}$ 계에서 $\mathrm{PuO}_{2}$ 의 환원 시 $\mathrm{Li}_{2} \mathrm{O}$ 의 제한농도는 $3.6 \mathrm{wt} \%$ 이하), 양극에서 산소 또는 염소의 발생조건, 보조전 극을 사용한 양극과 음극의 전위차를 측정하고 그 영향을 분 석함으로써 양극의 안정성 유지 조건, 그리고 산소 이외 가 스의 발생조건 등을 규명하였다.

한편 국내에서는 한국원자력연구원과 서울대학교를 주요 연구기관으로 손꼽을 수 있으며 한국원자력연구원이 수년 전에 개발한 화학적 환원법은 다음과 같다[5]. 즉, 불활성 분위기하에서 그리고 용융 염화리튬의 매질 내에서 분말 형 태의 우라늄산화물을 리튬과 반응시켜 우라늄을 금속 형태 로 전환시킨 후 입자상의 우라늄금속을 염화리튬 용융액으 로부터 여과하여 회수하는 방법이다. 그 장치는 용융액의 고 온 $\left(650^{\circ} \mathrm{C}\right)$ 유지와 온도 제어를 위한 가열 시스템, 아르곤가 스 주입 및 배출 시스템, 리튬금속 공급 시스템으로 구성되 어 있으며 생성물이 반응기 하부의 여과기로 원활하게 배출 될 수 있도록 반응기 하부를 원추형 (경사 35도)으로 만들었 다. 그리고 반응기 상부의 두껑은 밀폐형으로 제작되었고 반 응기 내부의 혼합물을 섞어주기 위한 교반기, 용융액의 여과 를 위한 마그네시아 재질의 여과기가 장착되어 있어 종래의 어떤 반응기보다 반응시간이 단축되고 반응효율이 제고된 결과를 얻었다.
또 한국원자력연구원에서는 전해환원법에 의한 우라늄 금 속 제조법과 그 장치도 개발하고 있는데 이는 $\mathrm{LiCl}-\mathrm{Li}_{2} \mathrm{O}$ 용융 염계에서 전기적 환원작용을 이용하여 이산화우라늄을 우라 늄금속 형태로 전환시키는 방법이다〔6〕. 본 연구에서는 금 속전환과정과 리튬회수과정을 하나로 통합하여 공정의 단순 화를 꾀하였으며 화학적 환원법에서처럼 산화성이 큰 리튬 금속의 사용을 배제케 함으로써 공정의 안전성을 향상시키 고 아울러 우라늄산화물의 전환율을 향상시켰다 (Fig.5 참 조). $\mathrm{LiCl}-\mathrm{Li}_{2} \mathrm{O}$ 용융염계에서 이산화우라늄의 환원반응기구 는 다음과 같으며 온도 $650^{\circ} \mathrm{C},-2.592 \mathrm{~V}$ 이상의 인가전압하에 서 $\mathrm{Li}_{2} \mathrm{O}$ 가 전해반응을 통해 리튬금속과 산소를 발생시키며 2 단계에서 리튬금속이 우라늄산화물과 반응함으로써 $\mathrm{Li}_{2} \mathrm{O}$ 와 우라늄금속이

$$
\begin{array}{ll}
2 \mathrm{Li}_{2} \mathrm{O} \rightarrow 4 \mathrm{Li}+\mathrm{O}_{2} & \text { (1단계) } \\
\mathrm{UO}_{2}+4 \mathrm{Li} \rightarrow \mathrm{U}+2 \mathrm{Li}_{2} \mathrm{O} & \text { (2단계) }
\end{array}
$$

생성된다. 그밖에 또 한편의 특허에서는 위에서 언급한 $\mathrm{LiCl}-\mathrm{Li}_{2} \mathrm{O}$ 계 전해환원 장치에 장착되는 양극 $\left(\mathrm{Fe}_{3} \mathrm{O}_{4}\right.$ 봉형 $)$ 의 제조방법을 고안하였다\{7]. 이는 $\mathrm{Fe}_{3} \mathrm{O}_{4}$ 분말을 실리콘 튜브 에 충전시킨 후 냉간등압성형(cold isostatic press)하여 봉형 성형체를 형성하는 과정과 성형체를 $940 ~ 960^{\circ} \mathrm{C}$ 에서 진공 소결하는 과정을 포함한다. 지금까지 일반적으로 사용해온 백금 양극은 산소 이온 $\left(\mathrm{O}^{2-}\right)$ 의 산화반응으로 인하여 양극 표 면에 발생하는 산소가 백금과 반응하여 백금산화물층을 형 성하기 때문에 양극의 산화전위가 약 $1 \mathrm{~V}$ 이상 상승하며 이 는 금속전환율을 저감시킨다. 또 용융액 내에 존재하는 리튬 에 의해 부식이 일어나며 이것도 표면저항을 증가시키므로 금속전환율을 저감시킨다. 그러나 $\mathrm{Fe}_{3} \mathrm{O}_{4}$ 양극은 그러한 문 제점을 야기하지 않을 뿐만아니라 제조공정이 간단하고 제 조비용도 저렴하기 때문에 실용성이 매우 큰 장점을 가지고 있다.

\section{나. 회분식 및 연속식 전해정련장치}

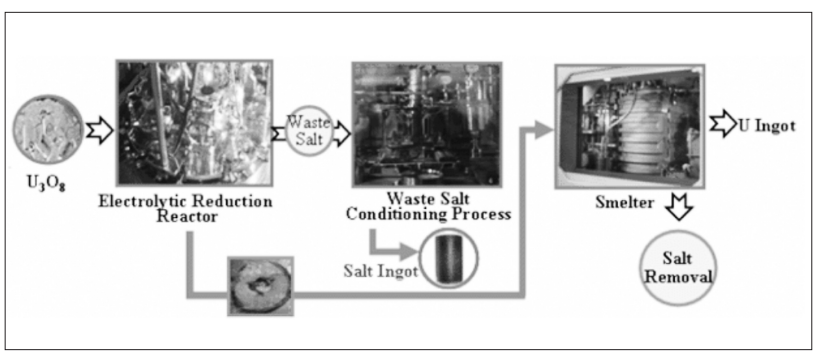

Fig. 5. An example of electroreduction process of uranium oxide. 
전해정련에 의한 우라늄 회수기술은 일찍이 미국의 아이 다호국립연구소에서 개발하여 EBR-II 원자로의 금속우라늄 형 사용후핵연료 처리에 적용한 바 있다. 그러나 이는 단지 EBR-II 핵연료 처리에만 국한되었을 뿐, 상용화로 발전되지 는 못 하였다. 그러나 우리나라를 비롯한 몇몇 나라에서는 핵확산저항성을 갖는 핵연료주기기술을 염두에 두어 PUREX(Plutonium and Uranium Extraction) 재처리 기술의 한 대안으로서 전해정련기술의 실용화를 위한 연구개발을 수행해오고 있다. 회분식 전해정련장치는 미국의 알곤국립 연구소에서 이미 많은 연구가 이루어져 왔으며 현재 한국, 일본, 미국, 러시아 등지에서 중점을 두고 있는 연구개발 방 향은 회분식 전해정련장치의 성능개선과 연속식 전해정련장 치의 개발 등이다.

일반적인 화학반응장치에 있어서 회분식과 연속식을 비교 할 때 동일한 처리용량을 갖는다면 그 장치규모에 있어 전자 가 후자보다 더 크다. 왜냐하면 전자에 있어서는 회분과 회 분 사이에 시간적 공백이 있기 때문이다. 회분식 조업에서는 한 회분의 조업이 끝나고 다음 회분의 조업에 대한 준비 작 업 즉, 원료공급, 장치의 운전초기화, 처리조건 조정 등 일련 의 작업이 필요하며 이 기간에는 조업이 일시 중단되므로 제 품을 생산하지 못 하기 때문이다.

연속식 전해정련장치 개발의 예를 들자면 미국의 J.E.Herceg 등 [8]이 고안한 것이 있다. 전해질로는 $\mathrm{LiCl}-\mathrm{KCl}$ 공융 용융염을 사용하며 드럼형 음극을 사용하여 연속적으 로 전해정련조업을 수행할 수 있도록 고안한 것이다. 핵연료 는 컨베이어벨트를 사용하여 전해조에 연속적으로 공급하며 수평 드럼형 음극이 전해질에 반쯤 잠겨서 회전함으로써 한 쪽에서는 전착이 일어나고 반대쪽에서는 전착물의 기계적 제거(scraping)가 가능하도록 한 것이다. 한편, 양극 쪽에서 는 공급된 핵연료 그 자체가 양극 역할을 하며 적정 인가전 압하에서 우라늄이 선택적으로 전착될 수 있도록 하였다. 지 르코늄과 몰리브덴 및 백금족 원소 등은 이온화되지 않고 즉, 전해질에 용해되지 않고 단체 상태로 양극에 남으며, 희 토류 원소는 전해질에 용해는 되지만 음극에 전착되지 않으

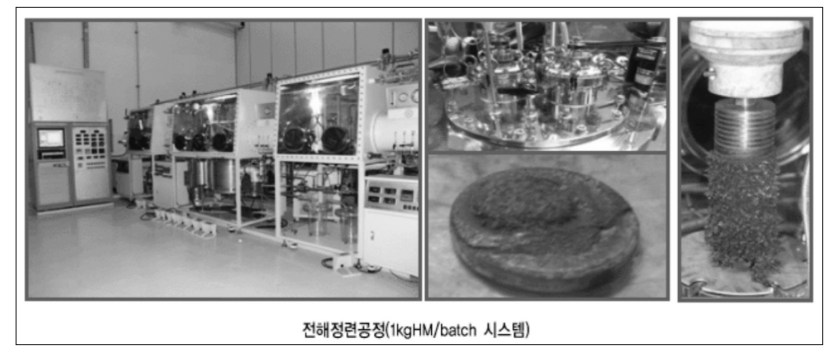

Fig. 6. Experimental electrorefining process in the KAERI.
므로 원소그룹별 분리가 가능하다. 이 조작에 이어 다음 단 계에서는 마찬가지 원리로 초우라늄원소들을 회수할 수 있 다. 그리고 다음 단계에서는 사용된 용융염을 재생하여 다시 사용할 수 있도록 하였다.

또 최근 미국 공개특허-2008/0296151〔9]와 한국 등록특 허-0880731〔10]에 수록된 전해정련장치의 한 예를 살펴보 면 Fig. 6 에 보는 바와 같다. 즉, 전해조의 음극재료로 탄소를 사용하면 음극에 전착된 우라늄의 자동탈리가 일어나므로 이 현상을 이용하여 별도의 기계적 탈리조작 없이도 전착물 을 회수할 수 있게 된다는 것이다. 이는 음극으로 사용된 탄 소가 격자구조를 가지므로 우라늄 원자가 이 격자 내에 인터 컬레이션(intercalation)되었다가 반응이 진행될수록 격자의 면간거리가 팽창하여 최외각 탄소격자의 결합강도가 낮아지 게 되며 이로 인하여 우라늄 전착물이 일정량 이상 성장하면 그 자체의 무게에 의하여 음극으로부터 탈리되어 전해조 바 닥으로 떨어지는 원리에 근거한 것이다 $\{11,12,13]$. 그러므 로 이 원리를 이용함으로써 연속 조업이 가능한 전해정련장 치를 고안하였다. 그리고 우라늄 석출물과 전이금속 잔사를 전해조로부터 연속적으로 이송할 수 있는 시스템을 고안하 여 이를 연속전해조에 덧붙였다. 장치 구성에 있어 양극부는 음극부를 감싸고 있는 원통형 바스켓으로 되어 있으며 이것 을 회전시킴으로써 전해질의 교반 역할도 겸하고 있다. 음극 부는 다수의 흑연음극으로 구성되어 있으며 그 하부에 우라 늄 회수조가 있어 음극으로부터 탈리되는 우라늄을 포집할 수 있도록 하였으며 또 이를 스크류컨베이어와 연결하여 전 해조 외부로 이송이 가능하도록 하였다. 이는 음극 표면에 부착되어 있는 우라늄을 기계적으로 제거할 필요가 없기 때 문에 장치가 간단해지는 것도 그 장점이다. 한편, 양극부의 하부에 쌓이는 전이금속 슬러지를 제거하기 위하여 또 하나 의 스크류컨베이어를 설치하고 이를 이용하여 전해조 바닥 으로부터 슬러지의 연속 제거가 가능하도록 하였다.

이 밖에도 한국원자력연구원에서 미국과 한국에 동시 출 원한 또 하나의 특허 내용은 음극에 전착된 우라늄을 기계적 진동 혹은 충격을 가하여 전극으로부터 탈리시켜 회수함으 로써 연속적인 전해정련조업이 가능하게 한 것이다 $\{14,15]$. 즉, 기계적 진동에 의하여 음극으로부터 탈리된 우라늄을 포 집하여 전해조 외부로 인출하는 우라늄 회수부와 양극바스 켓에 남아 있는 전이금속을 회수하기 위한 전이금속 회수부 로 구성되어 있으며, 전해조 밖으로 인출하기 위한 수단으로 컨베이어벨트를 고려하였다. 그리고 전해조 상부에 설치된 플레이트에 진동해머를 두어 진동이 연결봉을 통하여 음극 으로 전달될 수 있도록 고안하였으며 음극 재질로는 앞서 언 
급한 바와 같이 우라늄에 대하여 탈리기능을 갖는 흑연을 선 정하였다.

\section{다. 고온 액상 용융염의 취급}

본 연구에서 언급하고 있는 즉, 파이로처리 공정에서 다루 고 있는 용융염은 2 가지 종류가 있다. 하나는 산화물의 환원 을 위해 사용되는 $\mathrm{LiCl}-\mathrm{Li}_{2} \mathrm{O}$, 또 다른 하나는 전해정련/제련 에서 전해질로 사용되는 공융 용융염 $\mathrm{LiCl}-\mathrm{KCl}$ 이 그것이다. 이들은 각각 $650^{\circ} \mathrm{C}$ 와 $500^{\circ} \mathrm{C}$ 부근에서 취급되고 있으므로 고 온 액상 조건하에서 사용된다. 따라서 연속식 공정에서 그것 들을 어떤 장치에 공급하거나 유량을 조절하기 위해서는 특 수펌프가 필요하다. 상온에서 사용하는 일반 펌프가 아닌 고 온에서 사용 가능한 펌프라야만 한다. 유량을 조절할 필요 없이 단지 용융염의 이송만을 원한다면 진공이송법을 사용 할 수도 있을 것이다. 이는 한국특허-0622266[16]에 언급되 어 있는 바와 같이 일정 부피의 진공용기를 이용하여 일련의 기계적 조작 순서를 거치는 진공이송법이다.

또 이들 고온 용융염이 공기와 접촉하게 되면 공기 중의 산소 및 수분과 격렬히 반응하여 다른 물질로 변환되므로 반 드시 불활성 기체 분위기하에서 취급해야만 한다. 일반적으 로 밀폐된 알곤 분위기하에서 취급하는 것이 통례이다.

\section{라. 용융염 재생}

전해환원과정에서 전해질로 사용되는 용융염 $\mathrm{LiCl}$ 와 전해 정련 및 전해제련과정에서 사용되는 용융염 $\mathrm{LiCl}-\mathrm{KCl}$ 는 재 생해서 다시 사용할 수 있다. 회분식 운전에서는 여러 회분 동안 반복해서 사용할 수 있으며 연속식 운전에서도 일정한 한계시점까지는 사용할 수 있을 것이다. 한계시점에 도달하 기 전에는 용융염 내에 여러 가지 원소들, 특히 알카리 및 알 카리토 원소들 그리고 란탄족 원소들이 점점 누적되어 갈 것 이다. 사용후핵연료의 전해환원과정에서 배출되는 금속형 물질들이 전해정련장치에 공급되면 전이금속원소들은 양극 에 그대로 남아 있으나 알카리 및 알카리토 원소들과 란탄족 원소들, 그리고 악티늄족 원소들은 염화물 형태로 전환됨과 동시에 전해질에 용해되기 때문이다. 악티늄족 원소들 가운 데 우라늄은 전해정련과정에서 회수되고 초우라늄원소들은 그 다음 단계인 전해제련과정에서 회수되기 때문에 결국 전 해질에 남게 되는 원소들은 알카리, 알카리토 및 란탄족 원 소들이 주를 이룰 것이다. 만약 한 번 사용하고 난 전해질을 폐기물로 간주하여 폐기처분해버린다면 파이로처리 공정에 서는 엄청난 양의 폐기물이 발생하게 될 것이고 또 이로 인 하여 공정의 운전비용 또한 크게 증가하여 파이로처리기술
의 경제성에 악영향을 미칠 것이다.

전해환원과 전해정련/제련의 여러 회분에 걸쳐 반복 사용 한 $\mathrm{LiCl}$ 용융염과 $\mathrm{LiCl}-\mathrm{KCl}$ 용융염은 아직도 미량의 악티늄 족 원소와 상당량 누적되어 있는 란탄족 원소들을 함유하고 있으므로 용융염 재생에 앞서 그것들을 제거해주어야 한다. 이는 두 번에 걸친 정화공정(Drawdown)-첫 번째는 악티늄 족 제거, 두 번째는 란탄족 제거를 위한 전해 방식-을 통하여 수행할 수 있다. 첫 번째 공정에서 양극과 음극 간에 적절한 전위를 걸어주어서 악티늄족 원소들을 음극에 전착케 한다. 이 때 양극에서는 염소가스가 발생한다. 이어서 두 번째 공 정에서도 똑 같은 조작이 반복되는데 다만 전위차만 조절하 는 것으로 가능하다[16].

한국원자력연구원에서는 최근 여러 가지 아이디어에 착안 하여 용융염 재생법을 고안하고 있다. 그 중 한 가지는 쵸크 랄스키(Czochralski) 결정성장법을 도입하여 전해환원매질 로 사용한 용융염 $(\mathrm{LiCl})$ 을 정제하는 방법이다 $\{17,18]$. 이는 온도에 따라 용융염의 상태도 변화를 이용하는 방법으로 종 래의 세슘, 스트론튬 흡착법에 비하여 훨씬 유리한 방법이 다. 즉, 흡착제가 사용되지 않으므로 2 차 폐기물의 발생이 없고 연속 처리가 가능하므로 용융염 재생법으로 매우 적합 한 방법으로 사료된다. 결정성장 장치는 용융염의 고온 유지 를 위한 발열부, 순수염 결정을 인출하기 위한 인출봉, 인출 봉을 상하로 이동시키기 위한 승강기, 인출봉 하단에 원료 용융염이 용이하게 침투할 수 있게 하는 고정나사부 등으로 구성되어 있다. 기술의 실시예에서 보여준 바와 같이 LiCl$\mathrm{CsCl}$ 용융염계로부터 초기 $6 \mathrm{wt} \%$ 의 $\mathrm{CsCl}$ 농도가 용융염 표면 온도 $605^{\circ} \mathrm{C}, 30 \mathrm{rpm}$ 으로 회전하는 인출봉을 용융염 내 에 침적시켰을 때 $\mathrm{CsCl}$ 농도가 $0.28 \mathrm{wt} \%$ 에 지나지 않는 결 과를 얻을 수 있었다. 또 다른 한 가지 결과는 다음과 같다 $\lceil 19,20\rceil$. 전해환원 후 $\mathrm{LiCl}$ 전해질은 세슘, 스트론틈 등 방사 성을 띤 핵분열생성물질이 다량 함유되어 있으므로 이로부 터 $\mathrm{LiCl}$ 결정화법에 의하여 순수한 $\mathrm{LiCl}$ 를 분리해냄으로써 이를 전해질로 재사용할 수 있다는 것이다. 한편, 결정화되 지 않은 나머지 $\mathrm{LiCl}$ 에는 세슘, 스트론틈 등이 축적되어 그 농도가 점점 높아질 것이므로 최종적으로는 폐기처리하여야 만 할 것이다. 일례로 액상의 $\mathrm{LiCl}-\mathrm{CsCl}-\mathrm{SrCl}_{2}$ 용융염을 냉각 시키면 그 상태도 변화에 따라 액상과 고상이 공존하게 되므 로 즉, 순수한 $\mathrm{LiCl}$ 의 결정화가 일어나므로 상태의 한계점에 이를 때까지 온도를 내려 순수한 $\mathrm{LiCl}$ 결정을 회수하고 나머 지는 폐용융염 고화처리 과정을 거쳐 폐기처분하자는 것이 다.

일본의 Doryokuro Kakunenryo Kaihatsu Jigyodan에서 
출원한 미국 등록특허-5,264,159[21]는 폐용융염을 유리화 시키는 기술이다. 이는 금속 형태의 사용후핵연료를 건식 재 처리하는 과정에서 배출되는 전해질 용융염의 처분기술의 하나로 염화물로 구성된 전해질을 고온에서 붕산과 반응시 켜 산화물로 바꾸어준 후 적절한 첨가물을 가미하여 유리고 화체로 만들어 주는 기술이다.

\section{마. 전해제련에 의한 초우라늄원소 회수}

전해정련공정에서 우라늄을 분리해낸 후 전해질 속에는 미량의 우라늄을 비롯하여 초우라늄원소, 희토류원소, 알카 리 및 알카리토 원소들이 존재한다. 그러므로 전해정련이 끝 난 전해조 속에 제 2 음극을 설치하여 전해작업을 계속하면 미량의 우라늄과 초우라늄 원소들이 음극에 전착되기 시작 한다. 이 음극은 전해정련에서 우라늄을 전착시킬 때와는 달 리 액체음극을 사용하는 방법이 널리 알려져 있다. 보통은 카드뭄을 용융시킨 액체 카드뮴 $\left(500^{\circ} \mathrm{C}\right)$ 이 음극물질로 사용 되는데 일본 전력중앙연구소(CRIEPI)에서는 액체 비스무스 (Bi)를 사용함으로써 초우라늄과 란탄족 원소들 간의 산화환 원 전위차가 더 크게 벌어지기 때문에 좀 더 순도가 높은 초 우라늄 원소들을 회수할 수 있음을 발표하였다〔22〕.

최근 우리나라와 외국 연구소에서 출원한 특허를 중심으 로 이 분야의 연구개발 현황을 살펴보면 다음과 같다(Fig.7 참조). 전해정련과정에서 전해질 중에 잔류하는 우라늄의 함 량이 크면 전해제련과정에서 액체음극의 표면에 우라늄 덴 드라이트가 초우라늄원소보다 먼저 전착되므로 또 그 결정 이 점점 성장하여 음극 표면을 차단시키므로 이는 초우라늄 원소의 전착을 방해한다. 이러한 현상을 방지하기 위하여 미 국 아르곤연구소에서는 파운더(pounder)를 설치하여 그것 이 액체음극 표면에서 상하로 움직이게 함으로써 우라늄 덴 드라이트를 잘게 부수어 음극도가니 바닥으로 침전시키는 작용을 하도록 하였다 $\{27,28\rceil$. 또 일본 전력중앙연구소 $\lceil 29,30,31\rceil$ 에서는 액체음극 내부에 교반기를 설치하여 생성 되는 우라늄 덴드라이트를 잘게 부수어 역시 액체음극도가 니 바닥으로 침전시킬 수 있도록 하였다. 그러나 아직까지

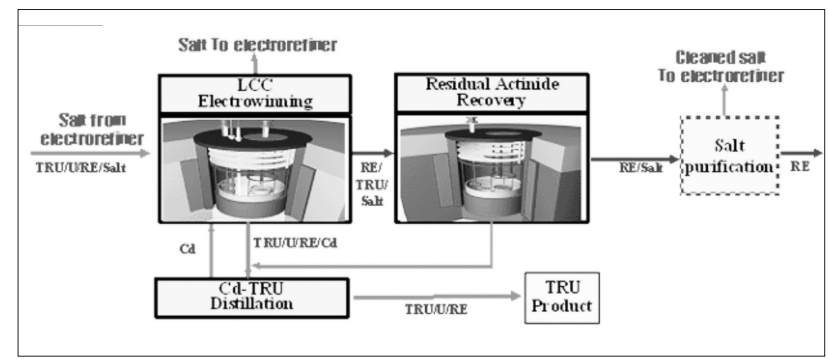

Fig. 7. An example of electrowinning process.
어느 방법도 썩 좋은 효과를 거두지는 못 하고 있다. 따라서 한국원자력연구원에서는 이러한 액체음극의 구조를 다소 변 경하여 덴드라이트 생성을 억제하고 초우라늄원소 회수율을 높일 수 있는 방안을 제시하였다〔23 26〕.

한국특허 10-0945,156〔23]에서는 전해조 내부에 이중의 도가니(외부 도가니 및 내부 도가니)를 설치하여 내부 도가 니에는 액상의 카드뮴을 채워 액체음극으로 작용케 하고 외 부 도가니는 전해질 용액 내에 완전히 잠기게 설치하고 교반 기를 액체음극 표면에 설치하여 전해 도중 생성하는 우라늄 덴드라이트를 내부 도가니의 외곽으로 밀어내는 작용을 하 도록 즉, 덴드라이트가 외부 도가니의 바닥으로 침전할 수 있도록 고안된 장치이다. 또 한국특허 10-0880,421〔24〕에 제시한 장치는 통합형 고체-액체 음극을 갖춘 것이다. 앞에 서 언급한 바와 같이 전해제련 과정에서 액체음극으로 초우 라늄원소를 회수하고자 할 때 용융염 전해질 중에 우라늄이 아직 많이 남아 있으면 즉, $\mathrm{Pu} / \mathrm{U}$ 의 비가 2.5 3.0보다 더 작 으면 우라늄 덴드라이트가 액체음극 계면에 생성되고 또 그 결정이 점점 성장하여 초우라늄원소의 전착을 방해하게 된 다. 이는 액체음극을 사용하기 전에 먼저 고체음극을 사용하 여 전해질에 남아 있는 우라늄을 좀 더 제거한 후 즉, $\mathrm{Pu} / \mathrm{U}$ 의 비가 더 커졌을 때 양극-고체음극 전기회로(1단계)를 양 극-액체음극 전기회로(2단계)로 전환시킴으로써 초우라늄원 소 회수를 시작하는 방법이다. 1단계 조업을 마친 후 고체 음극 표면에 전착된 우라늄을 갈퀴로 긁어 카드뮴 액체음극 속으로 포집되도록 하고 $\mathrm{Pu} / \mathrm{U}$ 의 비가 충분히 커진 후 전기 회로를 2 단계 조업으로 전환시킬 수 있도록 장치를 구성하 였다. 또 하나의 한국특허 10-0972,272〔25] 에서는 전해제련 장치의 운전 도중에 액체음극에 전착되는 금속의 전착량을 수시로 측정할 수 있는 장치를 고안하였다. 이는 운전 시작 후 액체음극의 무게 변화를 측정함으로써 시간에 따른 금속 의 전착량을 알 수 있을 뿐만 아니라 전해제련과정의 종말점 을 정확하게 파악할 수 있는 정보를 제공해 준다. 이 전해제 련장치는 용융염을 수용하는 제 1 용기, 액체금속 물질을 수 용하는 제 2 용기, 제 2 용기를 전해질 내에 고정시키는 지지체 를 포함한 액체음극부, 액체음극부의 무게를 측정하는 로드 셀 그리고 로드셀의 전기신호를 제어하는 제어부로 구성되 어 있다. 액체음극부의 무게를 측정하기 위해서는 어셈블리 가 지지부 고정부재의 조임으로부터 풀려나 자유로운 상태 가 되도록 해야 하므로 연속적인 무게 측정은 불가능하지만 일정시간 간격으로 측정하는 것은 가능하다. 그밖에 한국특 허 10-0962,182〔26〕에서는 앞에서 언급한 파운더 대신 그물 망식 또는 격자형 거름판을 장착하여 액체음극 표면에 형성 
되는 우라늄 덴드라이트를 주기적으로 제거해주는 장치를 개발하였다. 이 거름판은 상하, 좌우 또는 회전운동(액체음 극의 교반 역할도 겸함)이 가능한 구조로 되어 있으며 액체 음극으로부터 제거한 우라늄 덴드라이트는 전해조 내의 포 집부에 임시 보관함으로써 전해제련효율을 향상시킬 수 있 는 장치이다\{32〕. 이는 앞에서 언급한 방법 즉, 우라늄 덴드 라이트를 액체음극 바닥으로 침전시키기가 용이하지 않은 점을 개선한 것으로 덴드라이트가 성장하기 전에 거름판을 통과시켜 전착물이 음극 도가니 바닥에 가라앉게 함으로써 액체음극의 작용을 원활하게 하고 또 전착속도도 증가시킬 수 있는 방법이다.

\section{바. 폐용융염 고화처리}

전해환원, 전해정련 그리고 전해제련 과정에서 여러 회분 에 걸쳐 반복 사용한 용융염은 방사능을 띤 불순물이 점점 누적되어 더 이상 전해질로 사용할 수 없는 한계점에 도달하 여 결국 폐용융염이 되며, 이는 영구처분하기 전에 적절한 고화처리 방법을 동원하여 고화시켜야 한다. 그리고 그 고화 체는 처분용 용기 내에 밀봉 - 포장한 후 영구처분되어야 한 다. 따라서 최근 한국원자력연구원에서 출원한 이 분야의 특 허〔33)로 실리카고화체로 제조하는 방법이 있다 (Fig.8 참 조). 이는 여러 가지 금속염화물로 구성된 폐용융염을 실리 카 함유 무기물과 반응시켜 화학적 안정 물질로 전환시킨 후 거기에 고화제를 첨가하여 열처리함으로써 실리카고화체를 제조하는 방법이다. 따라서 최종 고화체는 열적, 수화학적 안정성이 크고 처분 용적도 크게 차지하지 않는다는 장점을 가지고 있다.

\section{사. 우라늠 잉곳 제조}

이것은 최종 제품의 하나인 우라늄 금속을 장기 저장하거 나 취급하기 쉬운 형태로 만들기 위하여 고체인 잉곳으로 만 드는 과정이다. 한국원자력연구원과 한국수력원자력주식회 사가 미국 특허〔34〕와 한국 특허〔35〕로 공동으로 출원하였 으며 그 주요 내용을 살펴보면 다음과 같다: 장치는 우라늄

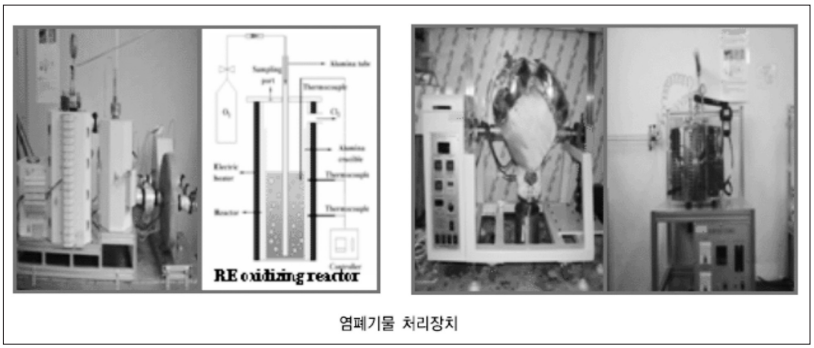

Fig. 8. An example of salt waste treatment process.
을 용융시키기 위한 유도코일의 가열기를 갖춘 용융로(1300 ${ }^{\circ} \mathrm{C}$ 로 운전), 진공챔버, 용융액 도가니, 주조틀 등으로 구성 되어 있으며 모든 우라늄 취급 과정은 불활성 분위기 내에서 이루어진다. 도가니는 지르코니아로 코팅된 그라파이트 재 질이 사용되며 주조틀도 그라파이트 재질로 되어 있다.

\section{IV. 결 론}

우리나라와 같이 에너지 자원이 빈약한 나라에서는 사용 후핵연료가 영구처분 대상인 폐기물이 아니라 일종의 에너 지 자원이기 때문에, 가까운 장래에 재활용하는 것은 어렵 더라도 장차 기술확립이 완료되고 국제사회로부터 실용화 전략이 허용되어 사용후핵연료를 재활용할 수 있을 때까지 안전하게 저장하는 것이 바람직할 것이다. 또 한편으로는 핵확산에 저촉되지 않을 만큼 핵확산저항성이 큰 핵연료주 기 기술을 연구개발하여 장차 이를 실용화하는 것이 두 가 지 관점에서 볼 때 좋을 것으로 생각된다. 즉, 하나는 매년 누적되어가는 사용후핵연료 관리문제에 대한 해결방안이 생기는 것이다. 폐기 대상이었던 우라늄과 초우라늄을 에너 지 자원으로 재활용함으로써 여타 에너지 자원의 소요량을 줄일 수 있다는 이점이 있을 것이고 또 다른 하나는 사용후 핵연료에 함유되어 있는 장반감기 핵종을 차세대 고속로에 서 단반감기 핵종으로 핵변환시킴으로써 최종 폐기물의 처 분조건을 완화시켜줄 수 있다는 이점도 있기 때문에 환경보 존 차원의 이점과 경제적 차원의 이점을 동시에 얻을 수 있 다는 것이다. 이러한 맥락에서 볼 때 지금까지 본 연구에서 수행한 특허동향분석은 파이로처리기술의 연구개발 방향을 정립하는 데에 귀중한 참고자료로 활용할 수 있을 것이다.

\section{감사의 글}

본 연구는 교육과학기술부에서 주관하는 원자력기술개발 사업의 일환으로 수행하였습니다.

\section{참고문헌}

[1] 장윤일, “고속로 개발 현황 및 전망”, 친환경 고속로 순 환핵연료주기 시스템 기술 개발 워크숍, 한국원자력학 회, May 26 (2010).

[2] 김의구, 신재철, 박정환, 김정국, 이한수, 특허청 보고서, "PWR 사용후핵연료의 부피 감용기술 특허동향", Oct. (2010). 
[3] 김은가, 서인석, 노성기, 류건중, 유재형, 조성수, KAERI/CM-1373/2010, “우리나라 원자력환경에 적합 한 고준위폐기물 관리기술 선행조사분석 연구”, 대덕원 자력포럼 (2010).

[4] Laszlo I. Redey, 미국등록특허-6,540,902, "Direct Electrochemical Reduction of Metal-Oxides" (2003).

[5] 김익수, 서중석, 홍순석, 이원경, 강대승, 박성원, 한국원 자력연구원, 한국등록특허-0514094, "우라늄 산화물 금 속전환 및 여과회수 장치” (2005).

[6] 서중석, 허진목, 최인규, 박성원, 박현수, 한국원자력연 구원, 한국등록특허-0593790, " $\mathrm{LiCl}-\mathrm{Li}_{2} \mathrm{O}$ 용융염계를 이용하여 산화물 핵연료로부터 핵연료 금속을 제조하는 방법, 상기 방법을 구현하기 위한 환원전극 및 상기 환 원전극을 포함하는 환원장치” (2006).

[7] 박성빈, 서중석, 박성원, 이성규, 주경, 서원선, 정형식, 한국원자력연구원, 한국등록특허-0684404, " $\mathrm{LiCl}-\mathrm{Li}_{2} \mathrm{O}$ 용융염계에서 산화물 핵연료의 전기화학적 금속전환반 응에 사용되는 봉형 $\mathrm{Fe}_{3} \mathrm{O}_{4}$ 양극의 제조방법 및 이를 이 용한 전기화학적 금속전환 셀” (2007).

[8] J. E. Herceg, J. G. Saiveau, L. Krajtl, 미국등록특허7,097,747, "Continuous process electrorefiner" (2006).

[9] Jong-Hyeon Lee, Young-Ho kang, Sung-Chan Hwang, Han-Soo Lee, Eung-Ho Kim and SeongWon Park, 미 국 공 개특 허 $-2008 / 0296151$, "Continuous Electrolytic Refining Device for Metal Uranium" (2008).

[10] 이종현, 강영호, 황성찬, 이한수, 김응호, 한국원자력연 구원, 한국등록특허-0880731, "금속우라늄의 연속식 전 해정련장치” (2009).

[11] Y. H. Kang, J. H. Lee, S. C. Hwang, J. B. Shim, E. H. Kim and S. W. Park, "Electrodeposition Characteristics of Uranium by Using a Graphite Cathode", Carbon, 44, pp. 3142-3145 (2006).

[12] 강영호, 이종현, 황성찬, 심준보, 김응호, “흑연 전극을 이용한 우라늄 전해정련 특성”, 방사성폐기물학회지, 5(1), pp.1-7 (2007).

[13] J. H. Lee, Y. H. Kang, S. C. Hwang, J. B. Shim, E. H. Kim and S. W. Park, "Application of Graphite As a Cathode Material for Electrorefining of Uranium", Nuclear Technology 162, pp.135-143 (2008).

[14] 이종현, 강영호, 황성찬, 이한수, 심준보, 김응호, 한국
원자력연구원, 한국공개특허-0039766 , “금속우라늄의 연속식 전해정련장치” (2010).

[15] Jong-Hyeon Lee, Young-Ho Kang, Sung-Chan Hwang, Han-Soo Lee, Joon-Bo Shim and Eung-Ho $\mathrm{Kim}$, 미국 공개특허-2010/0084265, “Continuous Electrolytic Refining Device for Recovering Metal Uranium" (2010).

[16] 정명수, 허진목, 조수행, 서중석, 박성원, 한국원자력연 구원, 한국등록특허- 0622266, "진공이송과 2중용기를 이용한 용융염 정량고화장치 및 방법” (2006).

[17] 이종현, 이한수, 김인태, 이윤상, 김응호, 한국원자력연 구원, 한국등록특허-0882578, "쵸크랄스키 결정성장 장 치 및 이를 이용한 염페기물의 정제 방법” (2009).

[18] Jong-Hyeon Lee, Han-soo Lee, In-Tae Kim, Yoon-Sang Lee and Eung-Ho Kim, 미국 공개특허2009/0139444, "Czochralski Apparatus for growing crystals and purification method of waste" (2009).

[19] 조용준, 김인태, 이한수, 한국원자력연구원, 한국등록 특허-1003955, “경막결정화법을 이용한 $\mathrm{LiCl}$ 염폐기물 의 재활용 방법 및 장치” (2010).

[20] 조용준, 정진석, 이한수, 김인태, "전해환원공정 발생 $\mathrm{LiCl}$ 염폐기물 재생기술 ", 방사성폐기물학회지 8(1), pp.57-63 (2010).

[21] Yasuhisa Ikeda, Yoshiyuki Yasuike, Makoto Yamaguchi, Hiroaki Kobayashi and Hiroshi Igarashi, Doryokuro Kakunenryo Kaihatsu Jigyodan, 미국 등록 특허-5264159, "Process for treating salt waste generated in dry reprocessing of spent metallic nuclear fuel"(1993).

[22] CEA report PG-DRRV/Dir/00-92, "Assessment of pyrochemical processes for separation/ transmutation strategies", Appendix-4, "Process developed by CRIEPI(Japan)", pp.75-82, Mar (2000).

[23] 백승우, 김시형, 심준보, 권상운, 김광락, 정흥석, 안도 희, 김응호, 한국원자력연구원, 한국등록특허-0945156, "악티나이드계 원소 회수를 위한 용융염 전해조" (2010).

[24] 권상운, 김광락, 백승우, 김시형, 심준보, 정흥석, 이종 현, 안도희, 김응호, 한국원자력연구원, 한국등록특허0880421, “고체-액체 통합형 음극 장치 및 이를 이용 한 악티나이드계 원소 회수 방법” (2009).

[25] 권상운, 정흥석, 심준보, 김정국, 김광락, 안도희, 백승 
우, 이한수, 김시형, 한국원자력연구원, 한국등록특허0972272, "액체음극의 무게 측정이 가능한 전해제련장 치, 그를 이용한 악티나이드계 원소 회수 방법 및 악티 나이드계 원소 전착량 모니터링 방법” (2010).

[26] 권상운, 김광락, 백승우, 김시형, 심준보, 정흥석, 박성 빈, 안병길, 안도희, 이한수, 한국원자력연구원, 한국등 록특허-0962182, "우라늄 덴드라이트 생성 및 억제형 액체음극장치 및 이를 이용한 악티나이드계 원소 회수 방법” (2010).

[27] J. E. Battles, K. M. Myles, J. J. Laidler and D. W. Green, Argonne National Lab., CMT Annual Technical Report, ANL-94/15 (1994).

[28] D. Vaden, B. R. Westphal, S. X. Li and T. A. Johnson, "Engineering scale liquid cadmium cathode experiments", Nuclear Technology, 162, pp.124-128 (2008).

[29] Sato makoto, "융해염 전기분해정제장치“, 일본특허 1997-316687 (1997).

[30] Shindo masato, "융해염 전기분해정제장치 “, 일본특허 1997-316851 (1997).

[31] T. Koyama, M. Iizuka, N. Kondo, R.Fujita and H. Tanaka, "Electrodeposition of uranium in stirred liquid cadmium cathode", J. Nuclear Materials, 247 pp. 227-231 (1997).

[32] 백승우, 윤달성, 김시형, 심준보, 안도희, "수지상 우라 늄 성장억제를 위한 액체카드뮴 음극구조 개발”, 방사 성폐기물학회지, 8(1), pp.9-17 (2010).

[33] 박환서, 김인태, 조용준, 김준형, 김응호, 한국원자력연 구원, 한국등록특허-0852383, "실리카 함유 무기물을 이용한 방사성 폐용융염의 고화처리 방법” (2008).

[34] Yoon-Sang Lee and Han-Soo Lee, 미국 공개특허2011/0056647, "Ingot-Casting Apparatus Using Uranium Deposits" (2011).

[35] 이윤상, 이한수, 한국원자력연구원, 한국공개특허2011-0026224, "우라늄 전착물을 이용한 잉곳 주조 장 치” (2011).

[36] M. A Williamson and J. L.Willit, ANL "Pyroprocessing Flowsheets for Recycling Used Nuclear Fuel", Nucl. Eng. \& Tech. Vol.43 No.4 (2011). 